\title{
Metal concentrations in fish otoliths in relation to body composition after laboratory exposure to mercury and lead
}

\author{
A. J. Geffen ${ }^{1, *}$, N. J. G. Pearce ${ }^{2}$, W. T. Perkins ${ }^{2}$ \\ 'School of Biological Sciences, Port Erin Marine Laboratory, University of Liverpool, Port Erin, Isle of Man IM9 6JA, \\ United Kingdom \\ ${ }^{2}$ Institute of Geography and Earth Sciences, University of Wales, Aberystwyth, Ceredigion SY23 3DB, United Kingdom
}

\begin{abstract}
Juvenile sand gobies Pomatoschistus minutus, plaice Pleuronectes platessa, and sole Solea solea were exposed to high or low levels of mercury or lead for $45 \mathrm{~d}$ in the laboratory. Points on the otolith corresponding to the core (pre-treatment), the start of exposure, midway through the exposure, and the termination of exposure were sampled and analysed by laser ablation - inductively coupled plasma mass spectrometry (LA-ICPMS). There were significant increases in the metal content of the goby and sole otoliths after exposure to mercury or lead, and the differences between the treatment levels for each element were significant. Plaice otoliths showed little increase in metal accumulation, and the difference between treatments was not significant. The relationship between exposure level, otolith metal concentration, and the metal concentration in fish muscle tissue was complex. In general, lead accumulated faster in the otolith and uptake was higher at low exposure levels. Mercury concentrations in fish tissue generally paralleled the concentration measured in the otoliths and the exposure level. Lead concentrations in fish otoliths were inversely related to tissue concentrations.
\end{abstract}

KEY WORDS: Otolith microchemistry · Heavy metals · Otolith composition

\section{INTRODUCTION}

Fish otoliths are composed primarily of calcium carbonate formed by the accumulation of crystals on an organic matrix. During formation, trace levels of numerous other elements are incorporated into either the organic or inorganic portion of the otolith. The concentrations of these trace elements are thought to be influenced primarily by the environmental conditions experienced by the fish. For example, variations in the ratios of strontium to calcium (Radtke \& Targett 1984, Radtke 1989, Radtke \& Shafer 1992), iron to calcium (Gauldie et al. 1980), and the oxygen isotopes ${ }^{16} \mathrm{O}$ to ${ }^{18} \mathrm{O}$ (Kalish 1991b, Iacumin et al. 1992) have been linked to variations in water temperature experienced by the fish. Changes in these ratios have also been used to demonstrate the migratory patterns of anadra-

\footnotetext{
•E-mail: geffen@iverpool.ac.uk
}

mous and estuarine-dependent fishes (Nelson et al. 1989, Lecomte-Finiger 1992, Northcote et al. 1992, Secor 1992, Thorrold et al. 1997). Cyclic variations in the trace element composition across otolith sections have been used to verify ageing by comparison with visible annuli (Radtke \& Targett 1984, Seyama et al. 1991, Radtke et al. 1993). Radioisotope ratios have also been measured to determine the age of otolith cores and thus verify ages determined by visual bands, or to determine longevity in certain species (Campana et al. 1990, 1993, Fenton \& Short 1992, Kalish 1993).

More detailed studies of otolith composition have made use of analytical techniques with very low detection limits for a wide range of elements. These studies have demonstrated that otoliths naturally contain many trace elements, including heavy metals, and that there are consistent differences in the composition of the otoliths for fish inhabiting different areas. This information is valuable for stock discrimination (Edmonds et al. 1991, Gunn et al. 1992, Campana et al. 
1994, 1995, Thresher et al. 1994), as well as for examining the contribution of different nursery ground populations to recruited populations (Dove et al. 1996, Gillanders \& Kingsford 1996, Milton et al. 1997).

Much of the work describing the relationship between otolith composition and temperature or salinity variation is based on analysis of field collected material, and is thus phenomenological in content. Several recent studies have sought to determine the effects of various environmental and physiological factors on fish otolith composition under experimental or controlled conditions (Kalish 1991a, Gallahar \& Kingsford 1992, Townsend et al. 1992, Fowler et al. 1995a, b, Hoff \& Fuiman 1995).

The concentrations of heavy metals in otoliths have been related to both spatial and temporal changes in environmental pollution (Papadopoulou \& Moraitopoulou-Kassimati 1977. Protasowicki \& Kosior 1988, Grady et al. 1989, Dove et al. 1996). Few studies have investigated either the rate of accumulation of heavy metals in otoliths under controlled conditions (Mugiya et al. 1991), or the relationship between exposure rate, otolith uptake and tissue accumulation of metals.

We analysed the changes in metal concentration across sections of the otoliths of fish exposed to different levels of mercury or lead. The tissue concentrations of mercury and lead were also determined in order that the pattern of metal accumulation in the otolith could be compared with tissue concentrations at the individual fish level.

\section{METHODS}

Plaice and sole were reared from eggs in the laboratory. After metamorphosis, the juveniles were held in $1000 \mathrm{l}$ round black tanks and fed on enriched Artemia until the start of the experiment. Juvenile gobies were collected with a fine mesh beach seine from a shallow sandy bay on the Isle of Man, UK, and transported to the laboratory. They were held in a $1000 \mathrm{l}$ round black tank and fed on enriched Artemia until the start of the experiment. The holding tanks were supplied with flowing seawater at $12^{\circ} \mathrm{C}$ and illuminated with fluorescent lighting set to give a photoperiod of $14 \mathrm{~h}$ light: $10 \mathrm{~h}$ dark

To initiate the experiment, the fish were removed from the holding tanks and injected intra-peritoneally with $0.1 \mathrm{ml}$ alizarin-complexone (100 ppm) to mark the otoliths. The effective dosage rate was $1 \mathrm{mg} \mathrm{g}^{-1}$ fish weight. The alizarin-complexone did not contain any metal impurities that would have contributed lead or mercury to the otoliths or fish muscle tissue. For the duration of the experiment, $45 \mathrm{~d}$, up to 10 fish of each species were held in $30 \mathrm{l}$ round black tanks. Tanks were randomly assigned to 1 of 5 treatments: control high lead, low lead, high mercury or low mercury. Each treatment was replicated in 2 tanks. Water in the tanks was changed every $3 \mathrm{~d}$ and oxygen levels and water mixing maintained with gentle aeration. Illumination was provided by fluorescent lighting set to give a photoperiod of $14 \mathrm{~h}$ light: $10 \mathrm{~h}$ dark. The fish were fed with Artemia nauplii and the wild-caught splashpool copepod Tigriopus spp.

Metal enrichment was achieved by adding either $\mathrm{HgCl}_{2}$ or $\mathrm{Pb}\left(\mathrm{NO}_{3}\right)_{2}$ from stock solutions to the water, with each water change, to achieve high and low dosage rates of 200 and $100 \mu \mathrm{g} \mathrm{l}^{-1}$ for lead and 20 and $10 \mathrm{\mu g} \mathrm{l}^{-1}$ for mercury. The metal concentrations did not remain constant, however, as there was some adsorption onto the walls of the tanks, as well as uptake by the fish. Water samples were collected weekly, acidified to $\mathrm{pH} 2$, and UV digested for $3 \mathrm{~h}$ before being analysed by AAS. The final mercury concentrations in the water were $7.35 \pm 1.34 \mu \mathrm{g} \mathrm{l}^{-1}$ in the high dose treatment, $2.1 \pm 0.3 \mu \mathrm{g} \mathrm{l}^{-1}$ in the low dose treatment, and 1.7 $\pm 0.28 \mu \mathrm{g} \mathrm{l}^{-1}$ in the control tanks. The lead levels were $25.0 \pm 4.9 \mathrm{\mu g}^{-1}$ in the high dose lead treatment, $13.8 \pm$ $2.4 \mu \mathrm{g} \mathrm{l}^{-1}$ in the low dose lead treatment, and $2.3 \pm 1.3$ $\mu \mathrm{g} \mathrm{l}^{-1}$ in the control treatment

When the experiment was terminated, all the fish were removed from the tanks and killed by freezing. They were then thawed, rinsed in distilled water, blotted dry and weighed individually. The sagittal otoliths were removed and the fish were refrozen in labelled vials. To determine metal concentrations in the fish tissue, each fish was cold digested in nitric acid (Analar) overnight, followed by hot digestion and dilution to final analytical volume. The reference materials for both mercury and lead determination were DORM1 (Dogfish muscle) and CRM 278 (Mytilus tissue). Mercury concentrations were determined from $10 \mathrm{ml}$ samples with a Varian 1275/VGA/AAS using a cold vapour technique (Leah et al. 1992). The limit of detection (LOD) for mercury in these samples was $0.04 \mu \mathrm{g} \mathrm{g}^{-1}$. Lead concentrations were determined from $5 \mathrm{ml} \mathrm{sam-}$ ples with a Varian Spectra 600 AAS fitted with a graphite furnace. The LOD for lead was $0.02 \mu \mathrm{g} \mathrm{g}^{-1}$.

The sagittal otoliths of each fish were mounted in epoxy resin (Epothin, Buehler) and sectioned through the core using an Isomet (Buehler) slow-speed diamond saw. The sections were polished with $1 \mu \mathrm{m}$ aluminium paste, and cleaned in distilled water in an ultrasonic bath.

The concentrations of mercury and lead at discrete points on the otolith sections were determined by laser ablation - inductively coupled plasma mass spectrometry (LA-ICPMS). This uses a modified, small spot version of the standard VG Laser Lab which is based on a $500 \mathrm{~mJ}$ Nd:YAG laser. Full instrumental descriptions 
are given in Pearce et al. (1992a). In this configuration, the laser beam is first apertured and then focused on the sample using a long working distance compound objective, to produce ablation craters approximately 20 to $30 \mu \mathrm{m}$ in diameter. Fracturing of the otolith occurred often, however, leaving holes up to $50 \mu \mathrm{m}$. The sequence of positions sampled was varied for each otolith to avoid any sequence-induced bias in the measurements. Visualisation of the otolith was done with a dissection microscope. This allowed orientation of the ablation points with respect to the alizarin mark, visible as a purple band in reflected light, which indicated the beginning of the experimental metal exposure (Fig. 1). Eleven isotope peaks were counted: ${ }^{24} \mathrm{Mg}$, ${ }^{42} \mathrm{Ca},{ }^{43} \mathrm{Ca},{ }^{44} \mathrm{Ca},{ }^{88} \mathrm{Sr},{ }^{138} \mathrm{Ba},{ }^{200} \mathrm{Hg},{ }^{202} \mathrm{Hg},{ }^{206} \mathrm{~Pb},{ }^{207} \mathrm{~Pb}$, and ${ }^{208} \mathrm{~Pb}$ (Table 1). Mercury and lead concentrations in the otoliths were calculated by blank subtraction and comparison with calibration curves derived from the standards which were analysed before each otolith block. Background counts of the argon gas were used as analytical blanks. Additional blanks and calibration standards $\left(0,20\right.$, and $\left.50 \mu \mathrm{g} \mathrm{g}^{-1}\right)$ for mercury and lead were made from spiked carbonate slurry dried and pressed into round cakes (Pearce et al. 1992, Westgate et al. 1994). The soda-lime glass, NIST 610, was the reference material used for lead calibration. Analyte counts from mercury $\left({ }^{202} \mathrm{Hg}\right)$ and lead $\left({ }^{208} \mathrm{~Pb}\right)$ at each ablation point were blank-subtracted, standardised to calcium $\left({ }^{43} \mathrm{Ca}\right)$ counts, and the concentration of metal calculated with reference to the calibration curves. The resulting values were normalised to constant calcium levels and expressed as $\mu \mathrm{g} \mathrm{g}^{-1}$. The isotopic ratios measured were compared to those expected from their natural abundances to check for any interference.

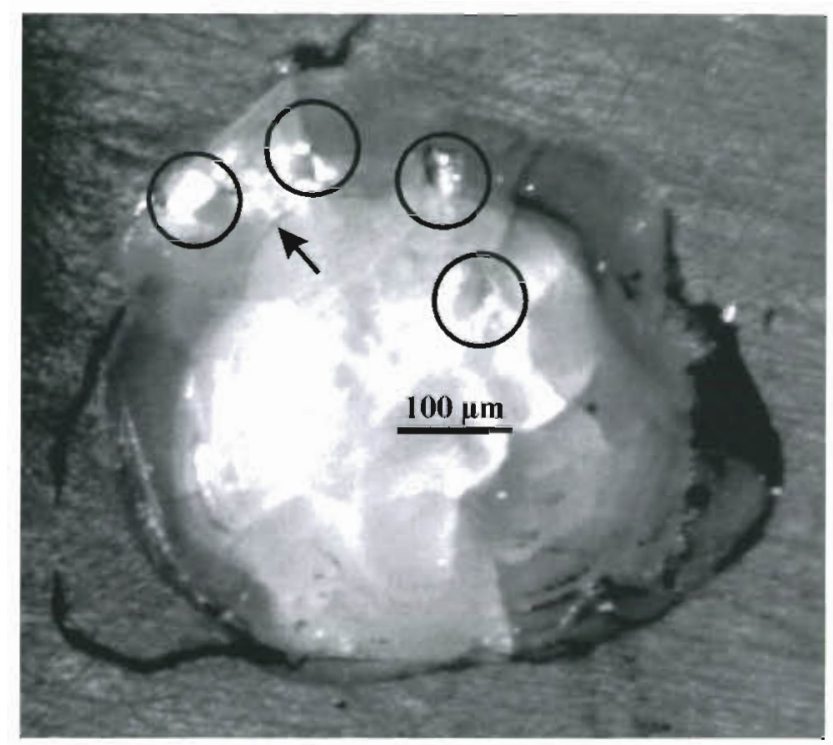

Fig. 1. Pomatoschistus minutus. Otolith of juvenile sand goby after sampling for mercury and lead concentrations by laser ablation - inductively coupled plasma mass spectrometry (LAICPMS). Ablation points are indicated by circles, and the arrow shows position of alizarin mark

Because the metal concentrations were calculated directly from external calibration standards, the counts for the different isotopes were not averaged or adjusted for natural abundance ratios.

The validity of assuming constant calcium concentrations across the otolith was checked by measurement of $\mathrm{Ca}$ on 3 otoliths from each species. These otoliths were repolished, cleaned, and carbon coated for microprobe (wavelength dispersive x-ray microanalysis, WDS) determination of Ca concentration.

Table 1. Summary data for the isotopes measured by LA-ICPMS, including limits of detection, average values measured for the calibration standards (counts $\mathrm{s}^{-1}$ ), and the range of values measured in the otolith samples. All values are area counts min ${ }^{-1}$

\begin{tabular}{|c|c|c|c|c|c|c|c|c|}
\hline $\begin{array}{l}\text { Element } \\
\text { /isotope }\end{array}$ & $\begin{array}{l}\text { Argon } \\
\text { gas } \\
\text { blank }\end{array}$ & $\begin{array}{l}\text { Limit of } \\
\text { detection } \\
\text { (LOD) }\end{array}$ & $\begin{array}{c}\text { NIST } 610 \\
\mathrm{~Pb}\end{array}$ & $\begin{array}{c}\text { Carbonate } \\
\text { standard } \\
0 \mu g g^{-1} \\
\mathrm{Hg}, \mathrm{Pb}\end{array}$ & $\begin{array}{c}\text { Carbonate } \\
\text { standard } \\
20 \mathrm{\mu g} \mathrm{g}^{-1} \\
\mathrm{Hg}, \mathrm{Pb}\end{array}$ & $\begin{array}{c}\text { Carbonate } \\
\text { standard } \\
50 \mathrm{\mu g} \mathrm{g}^{-1} \\
\mathrm{Hg}, \mathrm{Pb}\end{array}$ & $\begin{array}{c}\text { Range } \\
\text { measured } \\
\text { in samples }\end{array}$ & $\begin{array}{l}\% \text { of mea- } \\
\text { surements } \\
\text { above LOD } \\
(\mathrm{n}=308)\end{array}$ \\
\hline${ }^{24} \mathrm{Mg}$ & 1050.92 & 320.71 & 15372.36 & 675.5 & 834.5 & 1046.5 & $1413-78477$ & $100 \%$ \\
\hline${ }^{42} \mathrm{Ca}$ & 3612.33 & 749.42 & 36187.64 & 114950.8 & 127115.8 & 142406.8 & $6274-2115540$ & $100 \%$ \\
\hline${ }^{43} \mathrm{Ca}$ & 16127 & 6999.92 & 13829 & 20767 & 23730.75 & 27019.75 & $11767-431950$ & $100 \%$ \\
\hline${ }^{44} \mathrm{Ca}$ & 5351.83 & 3611.87 & 97305 & 335813.8 & 370483 & 404101.5 & $14819-6882769$ & $100 \%$ \\
\hline${ }^{88} \mathrm{Sr}$ & 153320.8 & 287332 & 17144817 & 6189862 & 6523676 & 8569072 & $1071-1803012$ & $87 \%$ \\
\hline${ }^{138} \mathrm{Ba}$ & 65.5 & 59.12 & 40594.55 & 849 & 1082.5 & 1323 & $46-327708$ & $100 \%$ \\
\hline${ }^{200} \mathrm{Hg}$ & 2636.08 & 6669.20 & 103321 & 24758.25 & 39644 & 63660.5 & $2011-136000$ & $84 \%$ \\
\hline${ }^{202} \mathrm{Hg}$ & 3396.17 & 8287.63 & 133974.7 & 31651.75 & 50704 & 81806 & $2604-188675$ & $88 \%$ \\
\hline${ }^{206} \mathrm{~Pb}$ & 204.67 & 479.65 & 24802.09 & 909.25 & 1325 & 2094.75 & $113-9022$ & $43 \%$ \\
\hline${ }^{207} \mathrm{~Pb}$ & 221.17 & 502.82 & 23224.45 & 668.5 & 1047.5 & 1729.75 & $119-5425$ & $37 \%$ \\
\hline${ }^{208} \mathrm{~Pb}$ & 280.92 & 269.03 & 56505.45 & 1791 & 2643.75 & 4148.75 & $6-14049$ & $96 \%$ \\
\hline
\end{tabular}


Average calcium concentration was $38.26 \pm 1.08 \%$ and there was no significant difference in Ca concentration across the otolith sections $\left(F_{3,23}=0.79\right)$.

Metal concentrations across the otolith were related to 4 periods: pre-treatment, initiation of treatment (identified by the alizarin mark), mid-treatment, and termination (the otolith edge). The accumulation of metals by individual fish was compared between treatments by repeated-measures ANOVA, adjusting the degrees of freedom for position on the otolith with Greenhouse-Geisser epsilon (SuperANOVA, Abacus Concepts 1989). Each species was analysed separately.

The relationship between otolith metal concentration and fish metal concentration was analysed by regression techniques, using tissue metal concentration as the independent variable and the metal concentration at different points on the otolith as the dependent variable. Linear regressions between fish tissue concentration and the metal accumulation expressed as a linear rate of uptake were also calculated. In all cases significant differences were judged at $\alpha=0.05$.

\section{RESULTS}

Goby survival in the exposure experiments was higher in the control tanks than in high and low levels of mercury and lead (Table 2). Plaice and sole experienced higher mortality than the gobies, irrespective of metal treatment.

Otolith growth was calculated from the measured distance between the alizarin mark to the edge of the otolith section. All fish in these experiments had some detectable otolith growth (67 to $160 \mu m$ ); the average increase in otolith size was $27 \pm 10 \%$.

Both mercury and lead were detected by LA-ICPMS analysis of the portion of the otolith deposited after the alizarin mark. On average, the mercury levels were 3 times higher in the otoliths of fish exposed to high mercury levels. Fish exposed to low lead levels had twice as much lead at the edge of the otoliths than fish in the control or high lead treatments.

Metal accumulation in the otoliths differed between species. The increases in otolith mercury concentration across the otolith sections (Fig. $2 a, c)$ were significantly different between treatments for gobies (repeated-measures ANOVA, $F_{6,30}=2.39$ ) and sole $\left(F_{2,28}=5.57\right)$. Mercury levels were highest in the otoliths of fish from the high mercury treatment. Similarly, lead concentrations increased significantly across the otolith (Fig. 3a, c), and the accumulation was significantly affected by exposure level for gobies $\left(F_{3,6}=8.15\right)$ and sole $\left(F_{3,6}=17.22\right)$. However, the greatest uptake of lead occurred in the low exposure
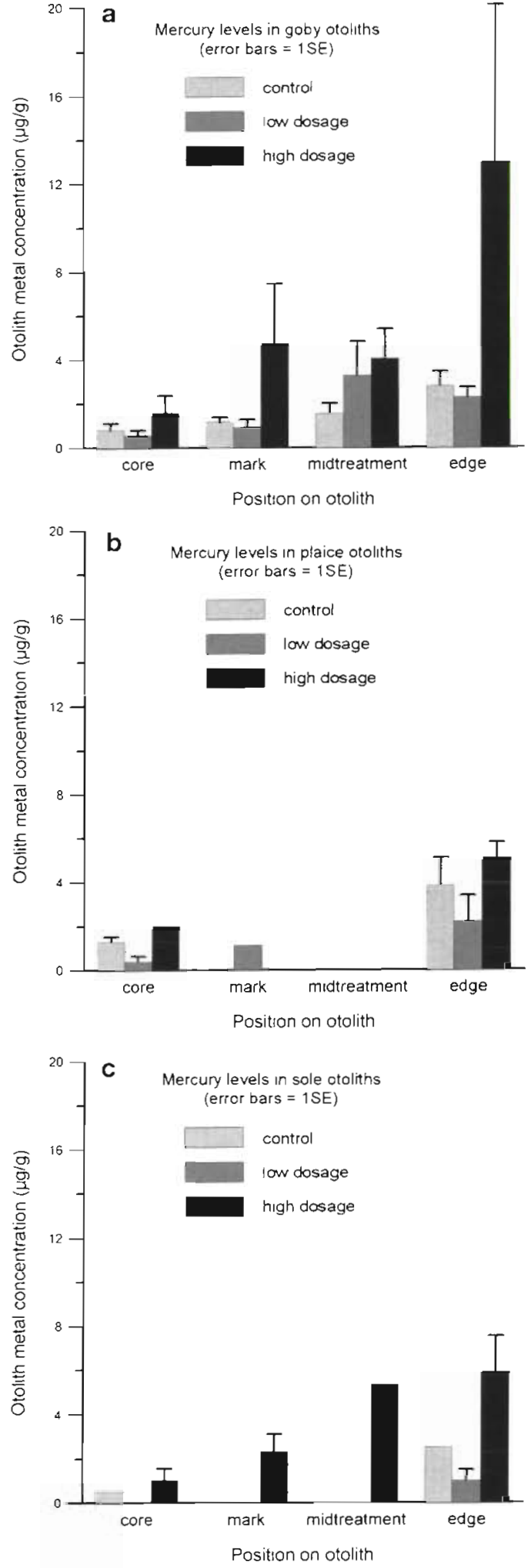

Fig. 2. Pomatoschistus minutus, Pleuronectes platessa and Solea solea. Concentration of mercury at different positions across the otoliths of (a) gobies, (b) plaice and (c) sole as determined by LA-ICPMS. Bar heights show mean values of all fish in that treatment $t_{i}$ error bars show $\pm \mathrm{SE}$ 
level treatment. Increases in metal levels in plaice otoliths were not significantly different between the different treatments (Figs. 2b \& 3b).

The rate of metal accumulation in the otolith was estimated for each individual as the difference between the metal concentration at the edge of each otolith and the concentration measured at the alizarin mark, expressed as a linear increase $\left(\mu_{g^{-1}} \mathrm{~d}^{-1}\right.$; Table 3$)$. There were no differences between the species in this calculated metal uptake rate, but the rate was significantly greater in the high mercury exposure as compared to control or low mercury exposure $\left(F_{2,28}=4.51\right)$ and significantly greater at low lead levels than at control or high lead exposure $\left(F_{2,35}=10.68\right)$.

Changes in the ratios of $\mathrm{Sr}: \mathrm{Ca}$ and $\mathrm{Mg}: \mathrm{Ca}$ across the otolith were analysed to give an indication of whether the variations measured in $\mathrm{Hg}$ and $\mathrm{Pb}$ could be attributed to physiological stress or ontogenetic effects rather than directly related to treatment concentrations. Both $\mathrm{Sr}: \mathrm{Ca}$ and $\mathrm{Mg}$ :Ca were significantly lower at the otolith core, but there were no significant differences between treatments (repeated-measures ANOVA: position on otolith $F_{\mathrm{Sr}: \mathrm{Ca}}=10.8$, df $3, \mathrm{p}<0.002$, $F_{\mathrm{Mg}: \mathrm{Ca}}=16.2, \mathrm{df} 3, \mathrm{p}<0.001$; treatment $F_{\mathrm{Sr}: \mathrm{Ca}}=0.82, \mathrm{df}$ $12, \mathrm{p}=0.6, F_{\mathrm{Mg} \mathrm{Ca}}=1.4$, df $\left.12, \mathrm{p}=0.3\right)$. The increases in $\mathrm{Sr}$ and $\mathrm{Mg}$ probably reflect the higher temperatures in the experimental tanks compared with the conditions experienced by the fish before the experiment.

Mercury concentrations in the fish tissue varied significantly between species and in relation to exposure rate. The concentration of mercury in goby tissue increased at higher exposure levels $\left(F_{2,16}=10.18\right)$ and was inversely related to fish size $\left(F_{1,16}=5.80\right.$; Fig. $\left.4 \mathrm{a}\right)$, although the interaction between treatment and fish size was not significant. The mercury concentration in sole tissue was not related to either treatment or fish size. There was no significant effect of exposure level on tissue concentration of mercury in plaice, but there was a significant exponential decline in tissue concentrations in larger fish $\left(F_{1,4}=1237.75\right.$; Fig. 4 b). Lead concentrations in fish tissue were not significantly different for gobies exposed to different treatment levels. Tissue lead concentrations did not vary in relation to goby size (Fig. 5a). The lead concentration in sole tissue was not related to either treatment or fish size. Lead concentrations in plaice did not differ with respect to the level of exposure, but tissue concentrations declined exponentially with fish size $\left(F_{1,6}=79.25\right.$; Fig. 5b).

These experiments provided a unique opportunity to examine the relationship between the concentration of metal accumulated in the tissue of a fish and the record of exposure as indicated by the concentrations measured at successive points on the otolith. In general, mercury levels in the fish tissue were positively corre-
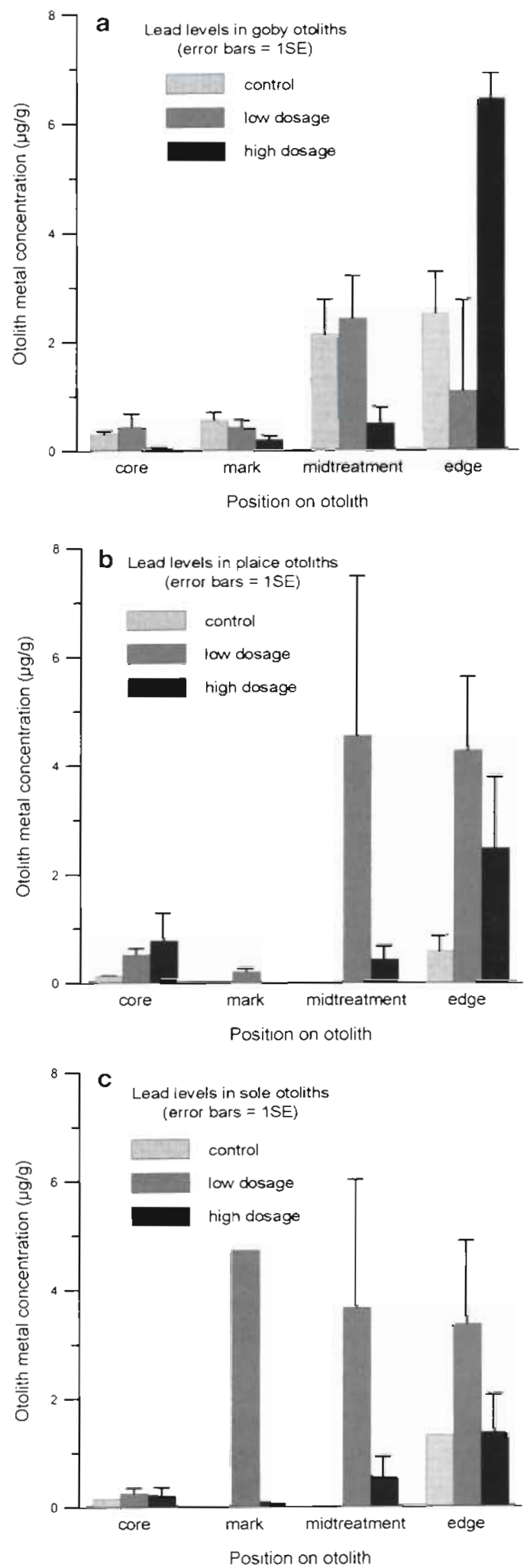

Fig. 3. Pomatoschistus minutus, Pleuronectes platessa and Solea solea. Concentration of lead at different positions across the otoliths of (a) gobies, (b) plaice and (c) sole as determined by LA-ICPMS. Bar heights show mean values of all fish in that treatment; error bars show $+\mathrm{SE}$ 
Table 2. Weights and tissue concentration of metals in gobies, plaice and sole exposed to high or low levels of mercury or lead. Weight and metal concentrations are means \pm 1 SD for fish from each treatment, replicates pooled. nd: sample concentration below LOD

\begin{tabular}{|c|c|c|c|c|c|c|c|c|c|}
\hline \multirow{2}{*}{$\begin{array}{l}\text { Species } \\
\text { (metal) }\end{array}$} & \multicolumn{3}{|c|}{ Control level } & \multicolumn{3}{|c|}{ Low level } & \multicolumn{3}{|c|}{ High level } \\
\hline & $\mathrm{n}$ & $\begin{array}{c}\text { Fish weight } \\
\text { (g) }\end{array}$ & $\begin{array}{l}\text { Tissue conc. } \\
\left(\mu \mathrm{g} \mathrm{g}^{-1} \text { wet wt }\right)\end{array}$ & $\mathrm{n}$ & $\begin{array}{c}\text { Fish weight } \\
\text { (g) }\end{array}$ & $\begin{array}{l}\text { Tissue conc. } \\
\left(\mathrm{\mu g} \mathrm{g}^{-1} \text { wet } w \mathrm{t}\right)\end{array}$ & $\mathrm{n}$ & $\begin{array}{c}\text { Fish weight } \\
\text { (g) }\end{array}$ & $\begin{array}{l}\text { Tissue conc. } \\
\left(\mu \mathrm{g} \mathrm{g}^{-1} \text { wet wt }\right)\end{array}$ \\
\hline Goby $(\mathrm{Hg})$ & 9 & $0.11 \pm 0.06$ & $0.51 \pm 0.21$ & 7 & $0.11 \pm 0.06$ & $29.75 \pm 18.29$ & 5 & $0.12 \pm 0.09$ & $43.93 \pm 13.43$ \\
\hline Goby (Pb) & 9 & $0.11 \pm 0.06$ & $0.34 \pm 0.14$ & 7 & $0.07 \pm 0.04$ & $0.89 \pm 0.54$ & 4 & $0.06 \pm 0.02$ & $3.03 \pm 2.19$ \\
\hline Plaice $(\mathrm{Hg})$ & 3 & $0.27 \pm 0.15$ & nd & 2 & $0.08 \pm 0.04$ & $50.20 \pm 20.36$ & 3 & $0.25 \pm 0.21$ & $90.01 \pm 40.38$ \\
\hline Plaice $(\mathrm{Pb})$ & 3 & $0.27 \pm 0.15$ & nd & 4 & $0.12 \pm 0.02$ & $1.66 \pm 1.01$ & 3 & $0.31 \pm 0.19$ & $2.29 \pm 1.89$ \\
\hline Sole $(\mathrm{Hg})$ & 1 & 0.10 & nd & 3 & $0.18 \pm 0.12$ & $35.49 \pm 13.28$ & 3 & $0.13 \pm 0.05$ & $58.20 \pm 21.92$ \\
\hline Sole $(\mathrm{Pb}))$ & 1 & 0.10 & nd & 3 & $0.12 \pm 0.12$ & $1.13 \pm 0.71$ & 5 & $0.29 \pm 0.33$ & $2.08 \pm 1.59$ \\
\hline
\end{tabular}

Table 3. Rate of metal accumulation $\left(\mu \mathrm{g} \mathrm{g}^{-1} \mathrm{~d}^{-1}\right)$ in the otoliths of gobies, plaice, and sole exposed to high or low levels of mercury or lead. Values shown are the average of all individuals in each treatment, pooled across replicates (mean $\pm 1 \mathrm{SD}$ ). The uptake rate was calculated as the difference between the concentration at the edge of the otolith and that measured at the alizarin mark indicating the beginning of exposure, expressed as a linear rate of accumulation over the duration of the experiment $(45 \mathrm{~d})$. nd = no data

\begin{tabular}{|lccc|}
\hline $\begin{array}{l}\text { Species } \\
\text { (metal) }\end{array}$ & Control & Low & High \\
\hline Goby $(\mathrm{Hg})$ & $0.08 \pm 0.10$ & $0.04 \pm 0.02$ & $0.31 \pm 0.29$ \\
Goby $(\mathrm{Pb})$ & $0.04 \pm 0.03$ & $0.12 \pm 0.05$ & $0.02 \pm 0.02$ \\
Plaice $(\mathrm{Hg})$ & $0.08 \pm 0.06$ & $0.04 \pm 0.04$ & 0.03 \\
Plaice $(\mathrm{Pb})$ & $0.01 \pm 0.01$ & $0.08 \pm 0.06$ & $0.03 \pm 0.03$ \\
Sole $(\mathrm{Hg})$ & 0.04 & nd & $0.11 \pm 0.06$ \\
Sole $(\mathrm{Pb})$ & 0.02 & $0.07 \pm 0.07$ & $0.02 \pm 0.02$ \\
\hline
\end{tabular}

lated with otolith concentrations measured at the midtreatment points only $\left(t=4.78, \mathrm{n}=12, \mathrm{r}^{2}=0.67\right)$, not with concentrations at the otolith edge or the mark indicating the initiation of exposure (Fig. 6). Lead levels in the fish tissue varied inversely with metal levels measured at the otolith edge $\left(t=-2.28, \mathrm{n}=30, \mathrm{r}^{2}=\right.$ $0.13)$. The calculated linear rate of metal uptake in the otolith varied in parallel with body tissue concentration for low mercury exposure (Fig. 7a), but varied inversely with tissue concentration for high mercury exposure and for lead (Fig. 7b). This suggests that, for some period after the initial exposure to mercury, this metal moves easily into the otolith, and its availability for deposition depends on the concentrations in the body. After longer exposure, there are mechanisms which can detoxify mercury in the body to allow it to be excreted. Lead, on the other hand, may accumulate in the otolith in the early days of exposure, but later, the fish may sequester lead in body tissue, thus removing it from circulation and making it less available for deposition in the otolith.
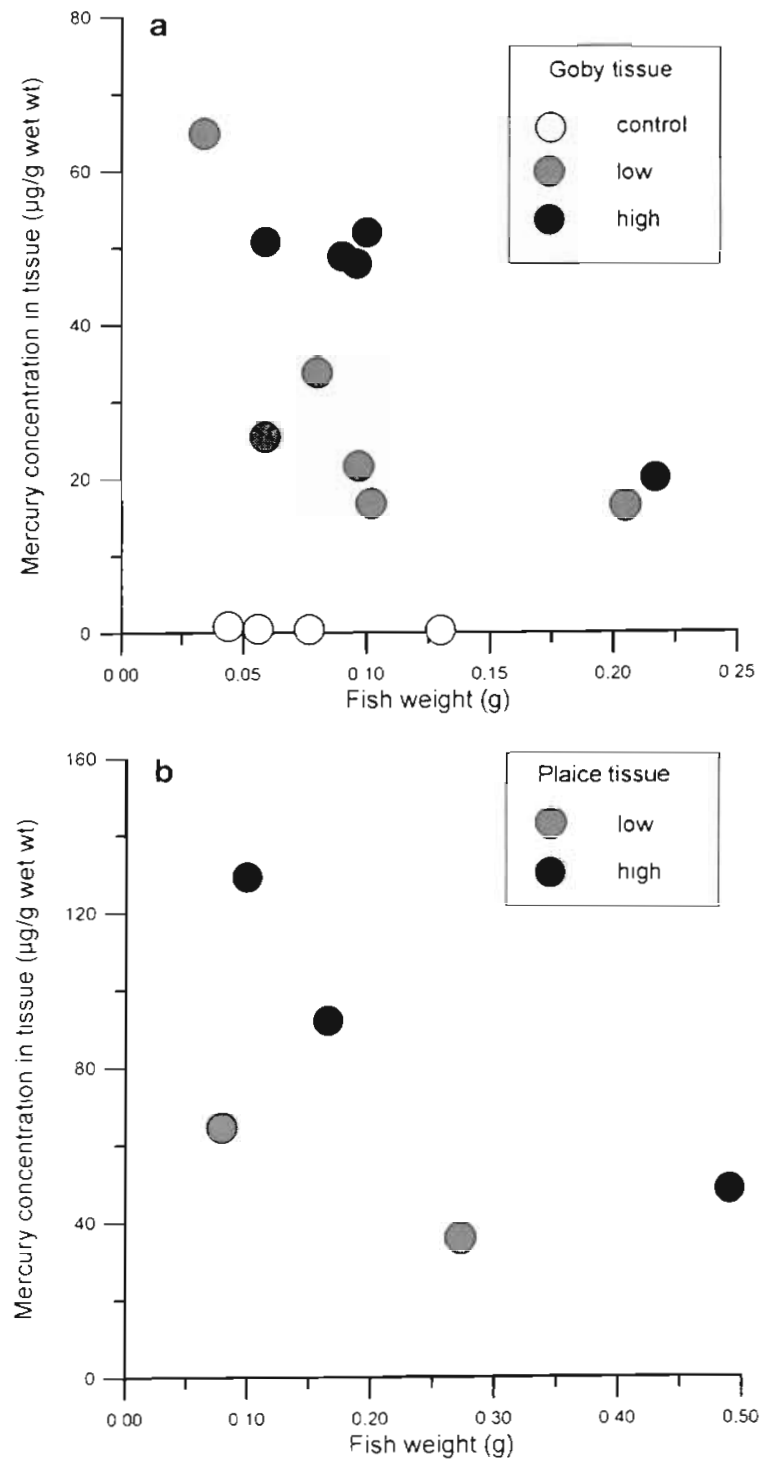

Fig. 4. Pomatoschistus minutus and Pleuronectes platessa Relationship between tissue concentration and weight for (a) gobies and (b) plaice exposed to 3 levels of mercury; mercury concentrations in plaice tissues in the control treatments were below the LOD. Points show values for individual fish 

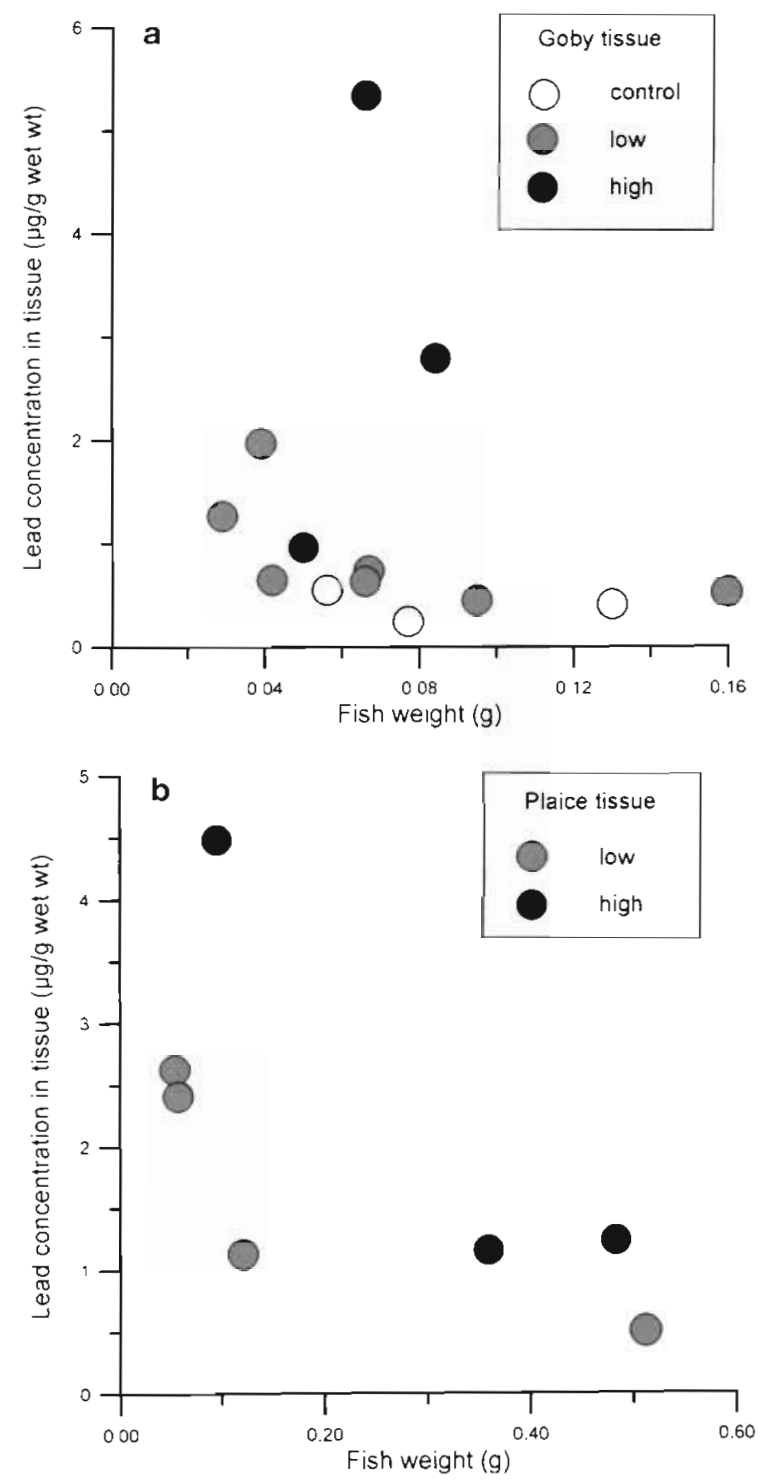

Fig. 5. Pomatoschistus minutus and Pleuronectes platessa. Relationship between tissue concentration and weight for (a) gobies and (b) plaice exposed to 3 levels of lead; lead concentrations in plaice tissue in the control treatments were below the LOD. Points show values for individual fish

\section{DISCUSSION}

The accumulation of heavy metals in fish otoliths depends on a number of factors, including the concentration in the environment, bioavailability, the physiological state of the individual fish laffecting the exchange rate between the external and internal environments), the mechanisms of different species for detoxifying different metals, the growth rate of the individual fish (affecting the rate of accumulation of otolith material), and the affinity of the calcium carbonate otolith for different metals. Because otoliths grow faster in faster-growing individuals, it is more likely that the rate of metal accumulation will be higher in situations where metal contamination is low enough not to impact fish growth. Where environmental contamination can be shown to result in reduced growth rates (Nash 1985, 1988), otolith composition could actually show reduced levels of metals, because otolith growth will be slow and the metal concentrations closer to the limits of detection. However, stressinduced disruptions in otolith growth may be associated with increased uptake of some metals (Fowler et al. 1995a).

Changes in the concentrations of different elements across the otoliths of individual fish can be caused by
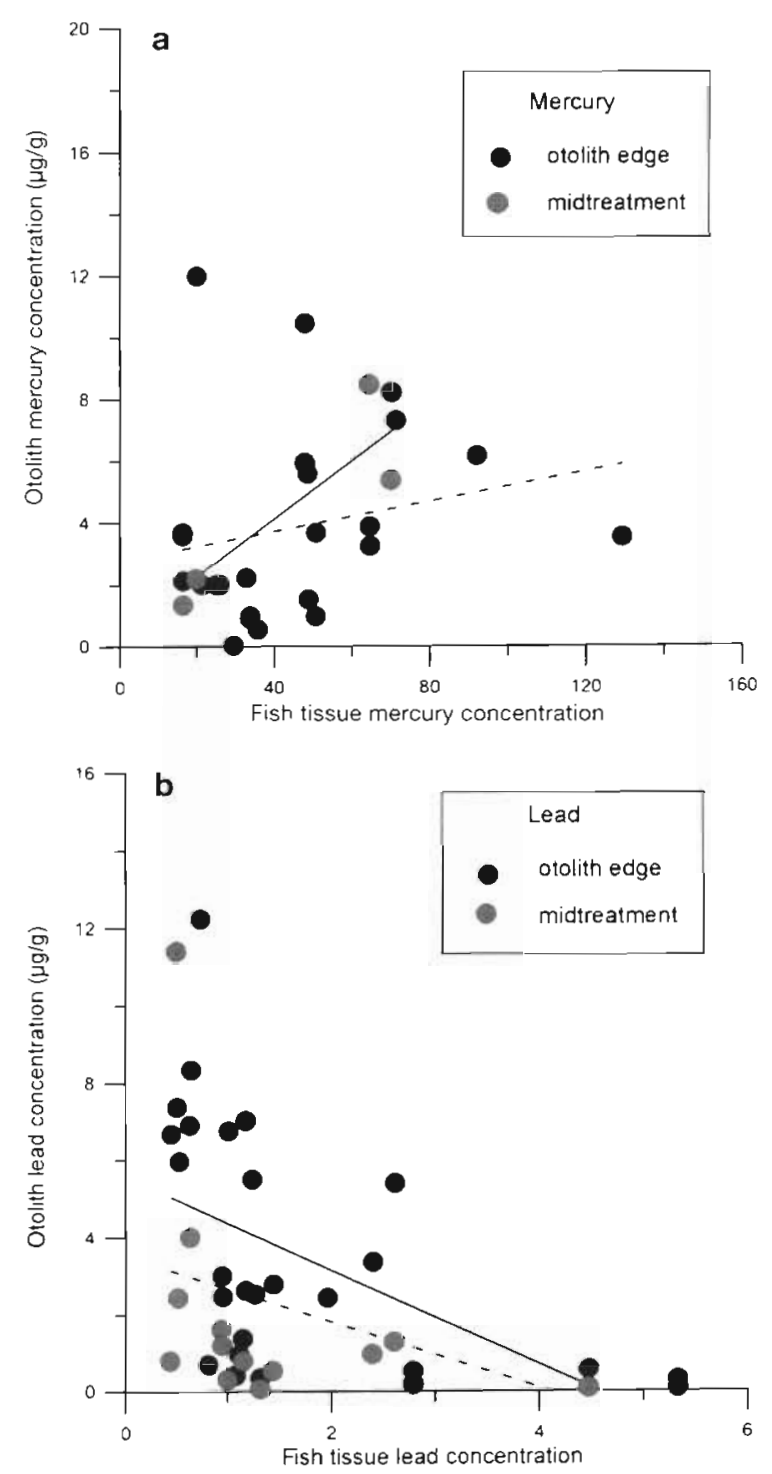

Fig. 6. Relationship between fish tissue concentration of (a) mercury or (b) lead and the concentrations measured at 2 positions on the otoliths of individual fish 

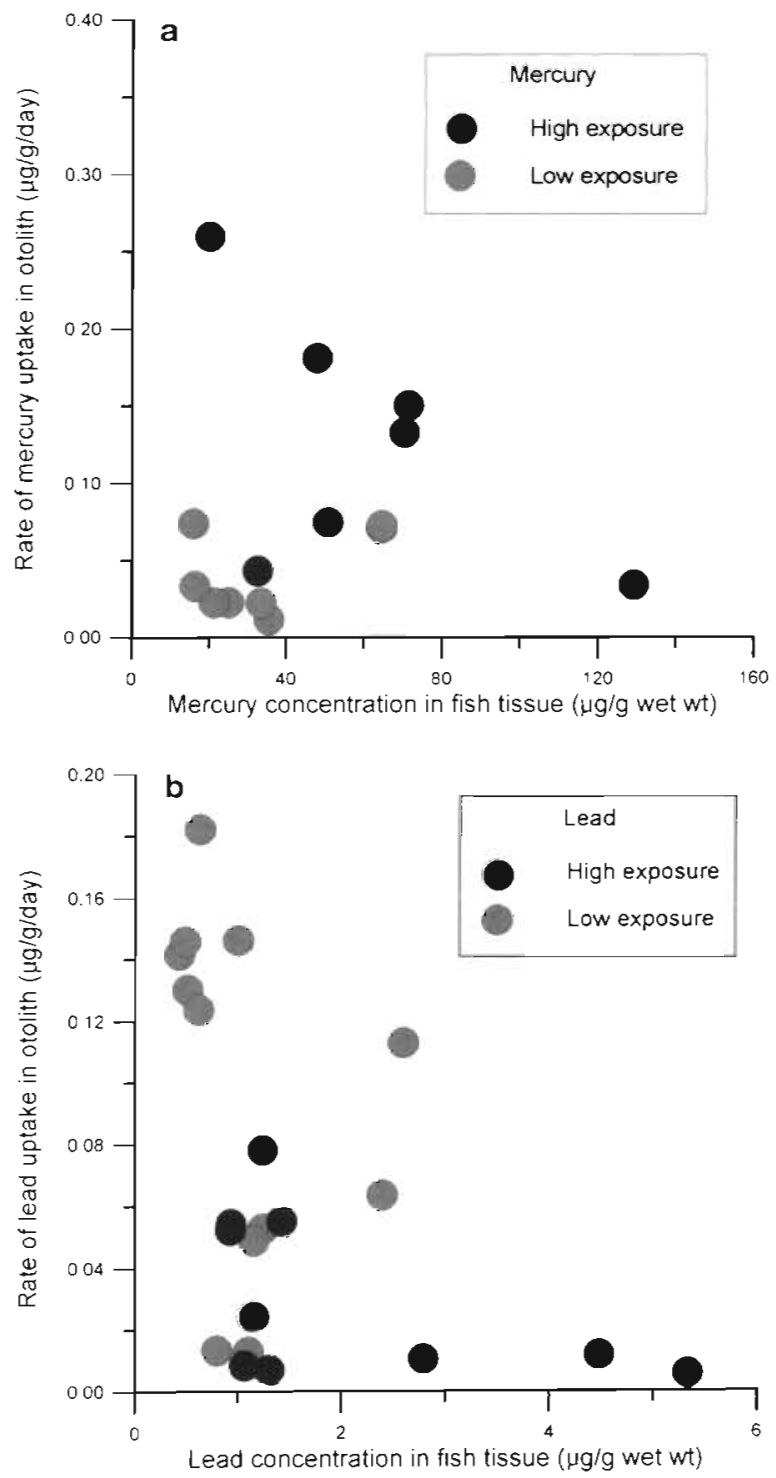

Fig. 7. Relationship between the rate of (a) mercury or (b) lead uptake to the otolith and the tissue concentration for individual fish

physiological changes during development, as well as by differences in the environmental conditions experienced. Fowler et al. (1995a) showed changes in composition, especially in $\mathrm{Sr}: \mathrm{Ca}$, across individual otoliths for fish raised in constant conditions, but physiological effects were not as strong as environmental effects on otolith composition. Developmental effects are unlikely to have produced the increases in mercury and lead observed in the fish in this study because the experimental period did not contain any significant developmental stages, and the fish were all post-metamorphosis at the initiation of the experiment.

It is generally believed that trace elements found in fish otoliths accumulate because of substitution of cal- cium by other divalent cations such as $\mathrm{Mg}^{2+}, \mathrm{Sr}^{2+}, \mathrm{Ba}^{2+}$, $\mathrm{Mn}^{2+}, \mathrm{Cu}^{2+}, \mathrm{Zn}^{2+}$ and $\mathrm{Pb}^{2+}$ and smaller monovalent cations, such as $\mathrm{Li}^{+}$(Fritz et al. 1990). However, it has also been suggested that $\mathrm{Mg}^{2+}$, and probably larger cations and anions, can be incorporated by becoming entrapped within the crystal lattice as crystal inclusions (Fritz et al. 1990, Rosenberg 1991).

Although the metal concentrations in the otoliths of gobies, plaice and sole exposed to mercury and lead were generally higher than in fish that were not exposed to these metals, there was not always a direct relationship between exposure and rate of metal incorporation. Low lead exposure resulted in higher rates of accumulation in the otolith. There were inverse relationships between otolith lead concentrations and body weight, and between the concentration of lead in recently deposited otolith material and tissue concentration. These results indicate that physiological mechanisms operate to regulate lead once it enters the body and that, at high concentrations, the lead is sequestered or in some way removed from circulation so that it does not reach the growing otolith. Lead is easily incorporated into many types of calcified tissue, and high lead exposure may in fact result in the shunting of lead into the skeletal (calcium phosphate) bones of the fish. This is the case for other vertebrates, including humans, where evidence of airborme lead incorporation can be monitored through the analysis of bone (Borjesson et al. 1997) or tooth composition (Gil et al. 1994, Selypes et al. 1997).

The mechanism of metal accumulation in fish otoliths has not been well described, especially in contrast with metal accumulation pathways in other fish tissue or the calcareous tissues of invertebrates. There are at least 2 means by which metals, including calcium, can be incorporated into the growing otolith. Small crystallising nuclei, calcospheres, have been observed to be formed and secreted from the otolithic membrane. These spherules migrate to the surface of the growing otolith and stick to the organic matrix of the otolith. Trace elements can be combined with the spherules within the epithelial cells. Structural evidence has been shown for this mechanism by SEM examination of shell (Arnold 1992) and histological studies of the labyrinth and otoliths (Wright 1990). Metals which are soluble in the blood can be carried to the epithelial cells and secreted in spherules onto the growing otolith.

In addition, calcium carbonate can precipitate directly out of solution and trace elements and metals which are also in the endolymph fluids can be incorporated into the growing otolith in this manner. Calcium reaches the endolymph primarily from the blood plasma (Wright et al. 1992), and it is likely that other trace elements can also follow this path. The precipita- 
tion of material from the labyrinth fluid is controlled by changes in $\mathrm{pH}$ (Wright 1991), under hormonal control (Mugiya 1986, 1987).

The incorporation of inorganic ions by both cellular secretion and fluid precipitation has been described for bivalve shells (Fritz et al. 1990), and differences in the patterns of accumulation of different metals has been ascribed to the behaviour of the different elements in terms of whether they can move directly into the extrapalladial fluid which bathes the growing shell, or whether they are metabolised and move into the shell by cellular secretion within spherules.

If different metals are accumulated into the otolith. by different pathways, then not only will the rate of accumulation differ, but there are also analytical consequences. When elements precipitate onto the otolith from extracellular fluid, they may be expected to have a more homogeneous distribution on the growing surface. However, this has been shown not to be the case for barium, which can crystallise directly onto the shell formation layer in discrete barite crystal $\left(\mathrm{BaSO}_{4}\right)$ clusters (Fritz et al. 1990). Metals which are deposited in the otolith from cellular secretion may also be incorporated as discrete crystals, or homogeneously if there is direct ionic substitution for calcium in the crystal lattice. By progressing to smaller spot sizes for sample analysis in order to resolve shorter time intervals, we may find that spatial heterogeneity at the micron scale will interfere with the precision of our determinations.

Fish have numerous mechanisms for dealing with toxic metals in the environment. Some elements may be metabolised, some sequestered so that they become biologically inactive, and others detoxified by conversion into other phases which are then excreted. Mercury belongs to the group of elements that induces metallothionien production, which detoxifies the metal (Pulsford et al. 1992). High and prolonged exposure can overwhelm the defence mechanisms, and excretion may not keep pace with accumulation. Thus mercury remained available for incorporation into the otolith, and its incorporation reflected both tissue concentration and exposure level. The inverse relationship observed between otolith lead and lead concentration in the body tissues could result from the sequestering of lead within nodules in body organs, making it less available for incorporation into the otolith. Sequestering of lead into melanomacrophages is documented for both fish (Pulsford et al. 1992) and bivalves (Thomson et al. 1985).

Differences between the 3 species studied here can be explained by differences in both metabolism and otolith formation. The otoliths of plaice have higher levels of protein and lower calcium levels than are assumed for other species (Zhang et al. 1991). It is not known how similar the otoliths of sole and plaice are, in terms of composition or growth rate. Flatfish generally have small otoliths, and thus the amount of material into which metals can be deposited is low. This would explain why sole and plaice otoliths had less mercury and lead, in general, than did goby otoliths. Gobies, on the other hand, have large otoliths, especially in relation to their small size. Their metabolic rate is higher than that of juvenile flatfish and thus their actual exposure to mercury and lead in these experiments would have been higher.

Acknowledgements. The authors thank S. Collins for analysing the metals in the fish tissue. This work was supported by grants from The Wellcome Trust and the Ministry of Agriculture, Fisheries and Food, Chief Scientists Group.

\section{LITERATURE CITED}

Abacus Concepts (1989) SuperANOVA. Abacus Concepts, Inc, Berkeley, CA

Arnold JM (1992) Nautilus embryology: a new theory of molluscan shell formation. Biol Bull (Woods Hole) 183: $373-374$

Borjesson J, Gerhardsson L, Schutz A, Mattsson S, Skerfving $\mathrm{S}$, Osterberg K (1997) In vivo measurements of lead in fingerbone in active and retired lead smelters. Int Arch Occup Environ Health 69:97-105

Campana S, Fowler A, Jones C (1994) Otolith elemental fingerprinting for stock discrimination of Atlantic cod (Gadus morhua) using laser ablation ICPMS. Can J Fish Aquat Sci 51:1942-1950

Campana SE, Gagne JA, McLaren JW (1995) Elemental fingerprinting of fish otoliths using ID-ICPMS. Mar Ecol Prog Ser 122:115-120

Campana SE, Oxenford HA, Smith JN (1993) Radiochemical determination of longevity in flyingfish Hirundichthys affinis using ${ }^{228} \mathrm{Th} /{ }^{226} \mathrm{Ra}$. Mar Ecol Prog Ser 100:211-219

Campana SE, Zwanenburg KCT, Smith JN $(1990){ }^{210} \mathrm{~Pb} /{ }^{226} \mathrm{Ra}$ determination of longevity in redfish. Can J Fish Aquat Sci 47:163-165

Dove SG, Gillanders BM, Kingsford MJ (1996) An investigation of chronological differences in the deposition of trace metals in the otoliths of two temperate reef fishes. J Exp Mar Biol Ecol 205:15-33

Edmonds JS. Caputi N, Morita M (1991) Stock discrimination by trace element analysis of otoliths of orange roughy (Hoplostethus atlanticus), a deep-water marine teleost. Aust J Mar Freshwat Res 42:383-389

Fenton GE, Short SA (1992) Fish age validation by radiometric analysis of otoliths. Aust J Mar Freshwat Res 43: 913-922

Fowler AJ, Campana SE, Jones CM. Thorrold SR (1995a) Experimental assessment of the effect of temperature and salinity on elemental composition of otoliths using laserablation ICPMS. Can J Fish Aquat Sci 52:1431-1441

Fowler AJ, Campana SE, Jones CM, Thorrold SR (1995b) Experimental assessment of the effect of temperature and salinity on elemental composition of otoliths using solution-based ICP-MS. Can J Fish Aquat Sci 52:1421-1430

Fritz LW, Ragone LM, Lutz RA (1990) Biomineralization of barite in the shell of the freshwater Asiatic clam Corbicula fluminea (Mollusca: Bivalvia). Limnol Oceanogr 35: $756-762$ 
Gallahar NK, Kingsford MJ (1992) Patterns of increment width and strontium:calcium ratios in otoliths of juvenile rock blackfish, Girella elevata (M.). J Fish Biol 41: $749-763$

Gauldie RW, Graynoth EJ, Illingworth J (1980) The relationship of the iron content of some fish otoliths to temperature. Comp Biochem Physiol 84A:19-24

Gil F, Perez Ml, Facio A, Villanueva E, Tojo R, Gil A (1994) Dental lead levels in the Galician population, Spain. Sci Total Environ 156:145-150

Gillanders B, Kingsford M (1996) Elements in otoliths may elucidate the contribution of estuarine recruitment to sustaining coastal reef populations of a temperate reef fish. Mar Ecol Prog Ser 141:13-20

Grady JR, Johnson AG, Sanders M (1989) Heavy metal content in otoliths of King Mackerel (Scomberomorus cavalla) in relation to body length and age. Contrib Mar Sci 31. $17-23$

Gunn JS, Harrowfield IR, Proctor CH, Thresher RE (1992) Electron probe microanalysis of fish otoliths - evaluation of techniques for studying age and stock discrimination. J Exp Mar Biol Ecol 158:1-36

Hoff GR, Fuiman LA (1995) Environmentally induced variation in elemental composition of red drum (Sciaenops ocellatus) otoliths. Bull Mar Sci 56:578-591

Iacumin l, Bianucci G, Longinelli A (1992) Oxygen and carbon Isotopic composition of fish otoliths. Mar Biol 113:5.37-542

Kalish JM (1991a) Determinants of otolith chemistry: seasonal variation in the composition of blood plasma, endolymph and otoliths of bearded rock cod Pseudophycis barbatus. Mar Ecol Prog Ser 74:137-159

Kalish JM (1991b) Oxygen and carbon stable isotopes in the otoliths of wild and laboratory-reared Australian salmon (Arnpis trutta). Mar Biol 110:37-47

Kalish JM (1993) Pre-bomb and post-bomb radiocarbon in fish otoliths. Earth Planet Sci Lett 114:549-554

Leah RT, Evans SJ, Johnson MS (1992) Mercury in flounder (Platichthys flesus L.) from estuaries and coastal waters of the north-east Irish Sea. Environ Pollut 75:317-322

Lecomte-Finiger $R$ (1992) The crystalline ultrastructure of otoliths of the eel (A. anguilla L. 1758). J Fish Biol 40: $181-190$

Milton DA, Chenery SA, Farmer MJ, Blaber SJM (1997) Identifying the spawning estuaries of the tropical shad, terubok Tenualosa toli, using otolith microchemistry. Mar Ecol Prog Ser 153:283-291

Mugiya $Y$ (1986) Effects of calmodulin inhibitors and other metabolic modulators on in vitro otolith formation in the rainbow trout, Salmo gairdneri. Comp Biochem Physiol $84 \mathrm{~A}: 57-60$

Mugiya Y (1987) Phase difference between calcification and organic matrix formation in the diurnal growth of otoliths in the rainbow trout, Salmo gairdneri. Fish Bull US 85: $395-401$

Mugiya Y, Hakomori T, Hatsutori K (1991) Trace metal incorporation into otoliths and scales in the goldfish. Carassius auratus. Comp Biochem Physiol 99C:327-331

Nash R.DM (1985) The distribution of fish in the Oslofjord and its possible relationship to pollution. In: Gray JS, Christiansen ME (eds) Marine biology of polar regions and effects of stress on marine organisms. John Wiley \& Sons Ltd, Chichester, p 389-400

Nash RDM (1988) The efferts of disturbance and severe seasonal fluctuations in environmental conditions on north temperate shallow-water fish assemblages. Estuar Coast Shelf Sci 26:123-135

Nelson CS, Northcote TG. Hendy CH (1989) Potential use of oxygen and carbon isotopic composition of otoliths to identify migratory and non-migratory stocks of the New Zealand common smelt: a pilot study. NZ J Mar Freshwat Res 23:337-344

Northcote TG, Hendy CH, Nelson CS, Boubee JAT (1992) Tests for migratory history of the New Zealand common smelt (Retropinna retropinna (Richardson)) using otolith isotopic composition. Ecol Freshwat Fish 1:61-72

Papadopoulou C, Moraitopoulou-Kassimati E (1977) Stable elements in skeletal formations of fish species from Greek waters. Thalassia Jugos\ 13:187-192

Pearce NJG, Perkins WT, Fuge R (1992) Developments in the analysis of carbonates by laser ablation inductively coupled plasma mass spectrometry. Anal Proc 29:280-281

Protasowicki M, Kosior M (1988) Long-term observations of selected heavy metals contained in otoliths of cod from the Southern Baltic. Kieler Meeresforsch 6:424-431

Pulsford AL, Ryan KP, Nott JA (1992) Metals and melanomacrophages in flounder, Platichthys flesus, spleen and kidney. J Mar Biol Assoc UK 72:483-498

Radtke RL (1989) Strontium:calcium concentration ratios in fish otoliths as environmental indicators. Comp Biochem Physiol 92A:189-193

Radtke RL, Hubold G, Folsom SD, Lenz PH (1993) Otolith structural and chemical analyses - the key to resolving age and growth of the Antarctic silverfish, Pleuragramma antarcticum. Antarct Sci 5:51-62

Radtke RL, Shafer DJ (1992) Environmental sensilivity of fish otolith microchemistry. Aust J Mar Freshwat Res 43: 935-951

Radtke RL, Targett TE (1984) Rhythmic structural and chemical patterns in otoliths of the Antarctic fish Notothenia larseni: their application to age determination. Polar Biol 3:203-210

Rosenberg GD (1991) The 'Vital Effect' on skeletal trace element content as exemplified by magnesium. In: Carter JG (ed) Skeletal biomineralization: patterns, processes and evolutionary trends, Vol I. Van Nostrand Reinhold, New York, p 567-577

Secor DH (1992) Application of otolith microchemistry analysis to investigate anadromy in Chesapeake Bay striped bass Morone saxatilis. Fish Bull US 90:798-806

Selypes A, Banfalvi S, Bokros F, Gyory E, Takacs S (1.997) Chronic lead exposure in children living in Miskolc, Hungary, on the basis of teeth lead levels. Bull Environ Contam Toxicol 58:408-414

Seyama H, Edmonds JS, Moran MJ, Shibata Y, Soma M, Morita M (1991) Periodicity in fish otolith Sr, Na, and K corresponds with visual banding. Experientia 47 . 1193-1196

Thomson JD, Pirie BJS, George SG (1985) Cellular metal distribution in the Pacific oyster, Crassostrea gigas (Thun.) determined by quantitative X-ray microprobe analysis. J Exp Mar Biol Ecol 85:37-45

Thorrold SR, Jones CM, Campana SE (1.997) Response of otolith microchemistry to environmental variations experienced by larval and juvenile Atlantic croaker (Micropogonias undulatus). Limnol Oceanogr 42:102-11.1

Thresher RE, Proctor CH, Gunn JS, Harrowfield IR (1994) An evaluation of electron-probe microanalysis of otoliths for stock delineation and identification of nursery areas in a southern temperate groundfish, Nemadactylus macropterus (Cheilodactylidae). Fish Bull US 92:817-840

Townsend DW, Radtke RL, Corwin S, Libby DA (1992) Strontium:calcium ratios in juvenile Atlantic herring Clupea harengus L. otoliths as a function of water temperature. J Exp Mar Biol Ecol 160:131-140 
Westgate JA, Perkins WT, Fuge R, Pearce NJG, Wintle AG (1994) Trace-element analysis of volcanic glass shards by laser-ablation inductively-coupled plasma-mass spectrometry-application to tephrochronological studies. Appl Geochem 9:323-335

Wright PJ (1990) The periodicity and formation of otolith increments in Salmo salar and Gasterosteus aculeatus. PhD thesis, University of Glasgow,

Wright PJ (1991) Calcium binding by soluble matrix of the

Editorial responsibility: Otto Kinne (Editor),

Oldendorf/Luhe, Germany otoliths of Atlantic salmon, Salmo salar L. J Fish Biol 38 : 625-627

Wright PJ, Talbot C, Thorpe JE (1992) Otolith calcification in Atlantic salmon parr, Salmo salar L., and its relation to photoperiod and calcium metabolism. J Fish Biol 40: $779-790$

Zhang Z, Runham NW, Pitcher TJ, Tsuji J, Ito J (1991) A new technique for preparing fish otoliths for examination of daily growth increments. J Fish Biol 38:313-316

Submitted: May 15, 1997; Accepted: February 6, 1998 Proofs received from author(s): March 30, 1998 